\title{
Radioactive dispersion analysis for hypothetical nuclear power plant (NPP) candidate site in Perak state, Malaysia
}

Shazmeen Daniar Shamsuddin*1, Nor Afifah Basri ${ }^{2}$, Nurlyana Omar ${ }^{3}$, Meng-Hock Koh ${ }^{4}$, Ahmad Termizi Ramli ${ }^{5}$, and Wan Muhamad Saridan Wan Hassan ${ }^{6}$.

1,2,3,4,5,6 Department of Physics, Faculty of Science, Universiti Teknologi Malaysia, 81310, Skudai, Johor, Malaysia.

*shazmeendaniar@gmail.com

\begin{abstract}
Malaysia is planning to build a nuclear power plant (NPP) by 2030 to diversify the national electricity supply and resources. Selection of an NPP site must consider various factors, especially nuclear safety consideration to fulfil the nuclear safety objectives. Environmental Risk Assessment Analysis is a part of safety requirements by the International Atomic Energy Agency (IAEA) prior to the NPP commissioning process. Risk Assessments Analysis (RIA) is compulsory for the NPP site evaluation. One of RIA methods are Radioactive Dispersion Analysis using probabilistic risk analysis software. It is also important to perform studies to estimate the impact to the neighbouring population in the case of a nuclear accident at the power plant. In the present work, aimed to study the impact of a hypothetical nuclear accident by simulating the dispersion pattern of radionuclides originated from a candidate site at Manjung, Perak. The work has been performed using the HotSpot Health Physics codes. Two types of radionuclides have been considered namely ${ }^{137} \mathrm{Cs}$ and ${ }^{131}$ I. In calculations, the initial concentration of radioactive materials of Fukushima Daiichi accident data are used which are $2.06 \times 10^{16} \mathrm{~Bq}$ and $1.68 \times 10^{17} \mathrm{~Bq}$ respectively for the two radionuclides. The result shows that the dispersion distance obtained from both software are not the same. It shows that ${ }^{137} \mathrm{Cs}$ and ${ }^{131} \mathrm{I}$ can be dispersed as far as $16 \mathrm{~km}$ and $80 \mathrm{~km}$ away from the site during radiological accident respectively, reaching major towns in Perak. Using HOTSPOT, the estimated total effective dose equivalent (TEDE) for ${ }^{137} \mathrm{Cs}$ and ${ }^{131} \mathrm{I}$ at major towns in Perak such as Lumut and Sitiawan are $1.2 \mathrm{mSv}$ and $9.9 \mathrm{mSv}$. As for Taiping, Ipoh, Kampar, and Teluk Intan the estimated TEDE is around $0.2 \mathrm{mSv}$ and 1.6 $\mathrm{mSv}$ respectively. In conclusion, the dispersion can reach as far as $80 \mathrm{~km}$ from the site. However, estimated annual effective dose is not more than 1 $\mathrm{mSv}$ limit, which is considered acceptable in the point of view of radiological health risk for human and the environment.
\end{abstract}

Keywords; nuclear power plant, radioactive, dispersion, accident

\section{Introduction}

Nuclear power is one of energy source in electricity sector which represent $13 \%$ to $15 \%$ of global electricity production. As of 2014, total nuclear electricity production is $2,410 \mathrm{TWh}$ around the world ${ }^{[1]}$.

Due to ever increasing demand of electricity, many non-nuclear countries have shown interest to include nuclear in their energy mix, including Malaysia. However, the driving forces are different in every emerging nuclear country ${ }^{[2]}$. In Malaysia's case, the ultimate 
driving force is to overcome over-dependence on fossil fuels and to serve as an alternative source to supply base load demand. Current scenario in Malaysia shows that 130 billion $\mathrm{kWh}$ gross was produced in 2011, 58 billion $\mathrm{kWh}(45 \%)$ of this from gas, 53 billion $\mathrm{kWh}$ (41\%) from coal, 7.6 billion $\mathrm{kWh}(6 \%)$ from hydro and 10 billion $\mathrm{kWh}(8 \%)$ from oil. In 2011, the Energy Commission showed 28.4 GWe capacity, which is $51.6 \%$ of this supplied by gas and $27 \%$ by coal ${ }^{[3][4]}$.

The decision to consider nuclear to be included in national energy mix was made in 2009. In June 2009, the government formally decided to consider nuclear power after a comprehensive energy policy study has been done. As to plan and coordinate the nuclear power development program, a Nuclear Power Development Steering Committee was set up, via three groups ${ }^{[3]}$. The pre-project activities were conducted discreetly by various government agencies, until the plan to build two units of $1000 \mathrm{MW}$ of nuclear power plant was formally announced in 2010. The government has established Malaysian Nuclear Power Corporation (MNPC) to lead the governmental agencies and industrial organization in the preparation activities. Series of studies are conducted to systematically examine and evaluate the national state-of-preparedness for the implementation of nuclear power program in Malaysia ${ }^{[4]}$. In May 2010, with a $\$ 7$ billion budget which the government had to build a nuclear power plant, the Ministry of Energy, Green Technology and Water was given the task to find a suitable site so that the first unit could be operating by 2021 . Thus, five possible locations have been identified in Peninsular Malaysia ${ }^{[3]}$. However, those locations are not revealed to the public.

Strict regulatory requirements must be fulfilled before a construction license is issued for a new NPP ${ }^{[5]}$. Site selection of nuclear power plant (NPP) is one of the compulsory activity in the feasibility study of nuclear technology development before a construction license was obtained. Selection of an NPP site must consider various factors, with special deliberation regarding the nuclear safety to fulfil the nuclear safety objectives stated in the international licensing standards ${ }^{[6]}$. The main objective is to protect the civilian and the environment from radiological risks of nuclear activities.

In the process of site selection, risk assessments are essential regulatory standards for the NPP site evaluation ${ }^{[7]}$. These assessments include the estimation of potential risks from normal routine and accidental releases of radionuclides from the new NPP to the surrounding. One of risk assessment methodologies is Radioactive Dispersion Analysis (RDA), which is used to estimate human health and environmental impacts from radionuclide dispersion and deposition in the region in normal operation or radiological accident scenario.

This paper presents the atmospheric RDA from hypothetical NPP candidate site in Perak State, Malaysia using HotSpot health physics code. The aim is to demonstrate how the software can be applied for radiological risk assessment of routine and accidental releases from the NPP.

\section{Model Description}

Radioactive dispersion and deposition in the atmosphere is usually analysed using Gaussian plume model. HotSpot use this model to project the dispersion and deposition of radionuclide in the atmosphere.

\subsection{Gaussian plume model}

The Gaussian dispersion equation ${ }^{[8]}$ is shown in Equation 1 below; 


$$
C(x, y, z)=\frac{Q}{2 u \pi \sigma_{y} \sigma_{z}} \exp \left(\frac{-y^{2}}{2 \sigma_{y}^{2}}\right)\left[\exp \left(\frac{-(z-H)^{2}}{2 \sigma_{z}^{2}}\right)+\exp \left(\frac{-(z+H)^{2}}{2 \sigma_{z}^{2}}\right)\right]
$$

(Eq.1)

Where,

$C=$ concentration at a given position $\left(\mu \mathrm{gm}^{-3}\right)$,

$Q=$ source emission rate $\left(g s^{-l}\right)$,

$x \quad=$ downwind $(m)$,

$y \quad=\operatorname{crosswind}(m)$,

$z \quad=$ vertical direction $(m)$,

$u \quad=$ average wind speed $\left(m s^{-I}\right)$ at the $H$

$H \quad=$ height of the release $(m)$.

While $\sigma_{y}$ and $\sigma_{z}$ are the standard deviations of the concentration distribution and frequently referred as dispersion or diffusion coefficient which indicates the spread of the plume in the $y$ and $z$ directions $(m)$ respectively. Normally, the values of $\sigma_{y}$ and $\sigma_{z}$ are determined based on the stability of the atmosphere and the values increases as the distance $x$ increases from the source.

For the past decades, Gaussian dispersion models have become a unique and efficient tool for the management of air quality. Thus, this model has been widely and successfully used for a wide range of studies of air quality in urban and industrial areas.

\subsection{HotSpot Health Physics Codes}

The HotSpot Health Physics Codes, or HotSpot program, gives a first-order estimation of the radiation impacts connected with the atmospheric release of radioactive materials. The program was made for the emergency response personnel and planner to prepare a quick, field-convenient arrangement of programming apparatuses to asses occurrences related to radioactive material.The product is additionally utilized for safety-analysis examination of facilities taking care of radioactive material.

The atmospheric dispersion models from this software are designed for short-range distance which is less than $10 \mathrm{~km}$, and short-term time which is less than a few hours of predictions in unobstructed terrain and simple meteorological condition. As stated by Homann and Aluzzi in 2014, HotSpot program provide a fast and usually conservative means for estimation of the radiation effects related to the atmospheric release of radioactive materials ${ }^{[9]}$.

\section{Study Area and Atmospheric Data}

\subsection{Study Area}

Perak State is in the West of Peninsular Malaysia. Perak has total area of $21,035 \mathrm{~km}^{2}$ with total population of $2,460,800$ in $2010^{\text {[10] }}$. The hypothetical NPP candidate site (will be referred to as CS1 throughout this paper) is in Manjung District (Coordinate - 4.324108 N, 100.564970 E). This site has less population than the entire district, hence may be suitable for an NPP site.

Manjung is the second smallest district in Perak State which covers an area of $1,074 \mathrm{~km}^{2}$. The nearest town are Lumut and Sitiawan, located around $18 \mathrm{~km}$ South East of the site. Total population in Manjung is 239,400 in 2010 with population density of 220 per km ${ }^{2}[10]$. Manjung's property is dedicated generally to agriculture, with an agrarian region of 833.75 
$\mathrm{km}^{2}$ or around $71.20 \%$ of Manjung District. Forest reserves represent another $168.81 \mathrm{~km}^{2}$ $(14.42 \%)$, while residential area is around $29.32 \mathrm{~km}^{2}(2.50 \%)$, and swampy region is 68.57 $\mathrm{km}^{2}$.

\subsection{Atmospheric Data}

Generally, Perak state has warm and sunny days, while its nights are cool the whole year through, with occasional rain in the evenings. Temperature in Perak ranges from $23^{\circ} \mathrm{C}$ to $33^{\circ} \mathrm{C}$, with humidity more than 82.3 percent. The annual rainfall in Perak measures about $3,200 \mathrm{~mm}$.

Atmospheric RDA analysis in this study utilizes meteorological data in year 2013 of Manjung district. The analysis of meteorological data for CS1 shows no significant difference compared to other areas in Peninsular Malaysia. The average wind speed is 3 to $5 \mathrm{~m} \mathrm{~s}^{-1}$ during non-monsoon season and 5 to $7 \mathrm{~m} \mathrm{~s}^{-1}$ during North East Monsoon (November to March). The maximum wind speed during 2013 is in October with the reading of $7.2 \mathrm{~m} \mathrm{~s}^{-}$ 1 . October is an inter-monsoon month, where the wind direction turned from Southwest direction to the opposite direction.

As shown in Figure 1 below, the most frequent wind direction in CS1 blows towards the East, throughout the year 2103. 13.8\% from total wind speed blows from the West direction in the range of 0.01 to $8.23 \mathrm{~m} \mathrm{~s}^{-1}$.

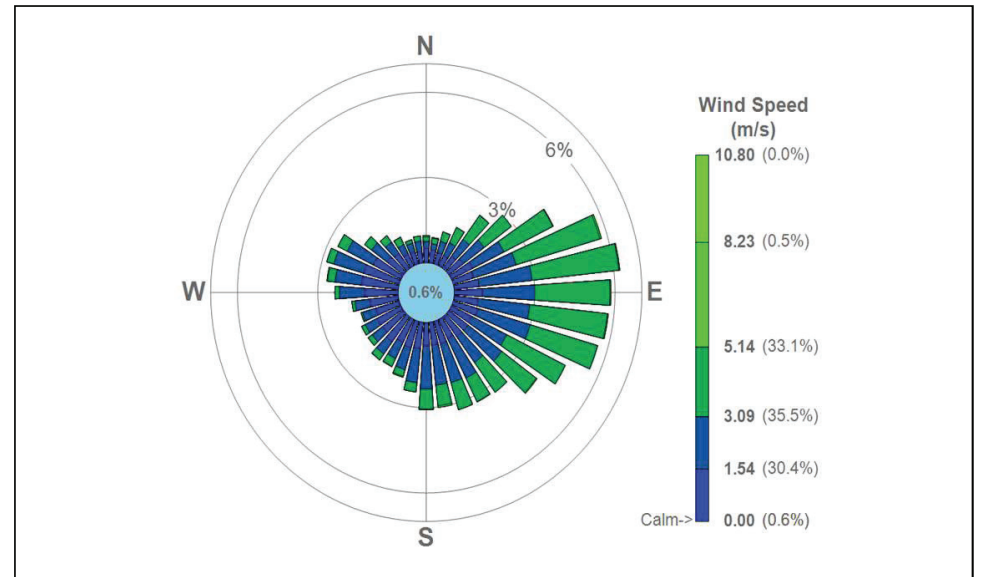

Figure 1. Wind Rose showing the direction of wind blew to and wind speed in 2013

While the wind data determined the direction of radioactive transport over the lands in east-central Malaysia, the rainfall data will determine the deposition of radionuclides to the ground.

\section{RDA Methodology}

This atmospheric RDA was conducted based on a postulated radiological accident scenario. The accident scenario is set to be equivalent to Fukushima Accident in 2011. Fukushima Accident is the most recent radiological accident due to failure of cooling system after a series of earthquakes, followed by tsunami at the Fukushima Dai-ichi NPP [11][12].

\subsection{Dispersion in Postulated Accident}


The dispersion simulation of a postulated radiological accident was conducted with reference to the studies on Fukushima Accident $2011^{[11][12][13]}$. The meteorological condition was set to the most frequent meteorological condition in the site, while the material at risk was set equivalent to Fukushima Accident to simulate the same scenario on the site. The parameters set for the simulation are stated in Table 1 below;

Table 1: Parameters for HotSpot Simulation

\begin{tabular}{|c|c|c|}
\hline Parameter & Features & Notes \\
\hline Dispersion Model & General Plume & - \\
\hline $\begin{array}{l}\text { Radionuclide (Material at } \\
\text { Risk) }\end{array}$ & I-131 and Cs-137 & {$[11][12][13]$} \\
\hline Deposition Velocity & $0.2 \mathrm{~cm} / \mathrm{sec}$ & {$[12]$} \\
\hline Material at Risk & $\begin{array}{l}\text { Cs-137: } 2.06 \times 10^{16} \mathrm{~Bq} \\
\mathrm{I}-131: 1.68 \times 10^{17} \mathrm{~Bq}\end{array}$ & {$[12]$} \\
\hline Sample time & 60 minute & {$[12][13]$} \\
\hline Wind data & $2.33 \mathrm{~ms}^{-1}$ & - \\
\hline Source height & $20 \mathrm{~m}$ & {$[12][13]$} \\
\hline Meteorological Condition & Stability class B & $\begin{array}{l}\text { Low sun and cloudy - average } \\
\text { meteorological condition in Malaysia }\end{array}$ \\
\hline
\end{tabular}

\section{Result on Postulated Accident}

From the meteorological data, the information was inserted in the HotSpot software to simulate the dispersion of Cs-137 and I-131 in CS1 by referring to Fukushima Accident scenario (Table 1).

Figures below shows the dispersion shape of Cs-137 and I-131 in the region. Since Hotspot can only simulate one wind direction at a time, 4 directions were selected to observe the dispersion shape towards major towns (Taiping, Ipoh, Kampar and Teluk Intan) in Perak (Figures 2 and 3). Dose conversion data for each radionuclide were listed in Table 2 and 3 .

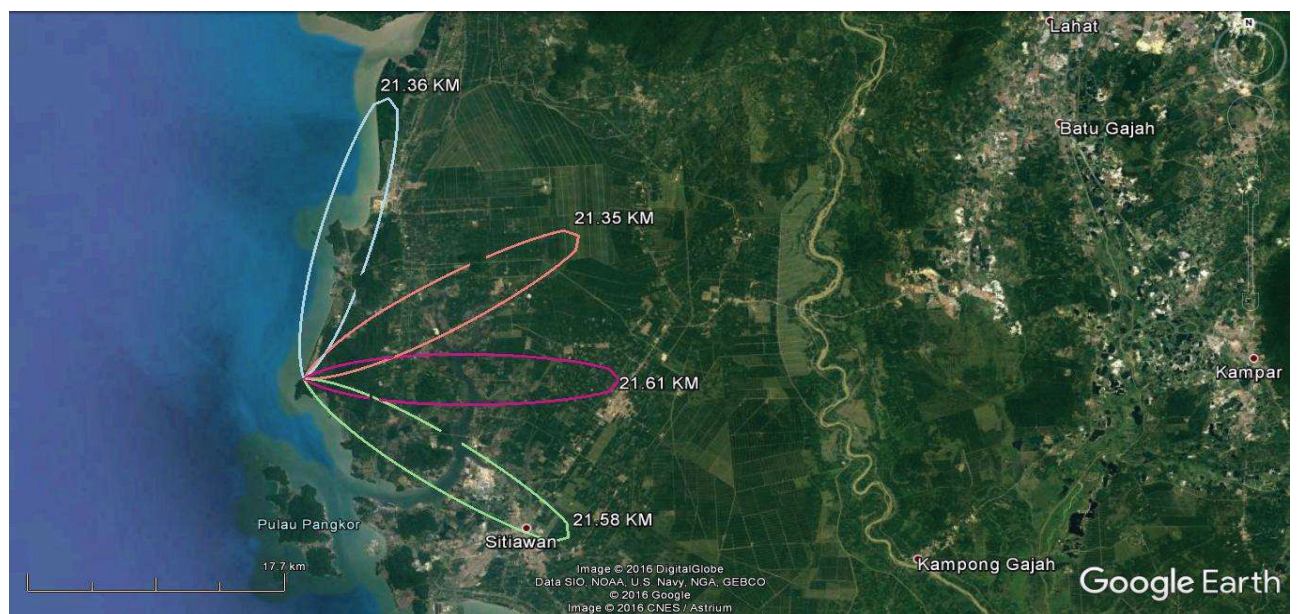

Figure 2: Cs-137 Total Effective Dose Dispersion in the Region in 4 Wind Direction 


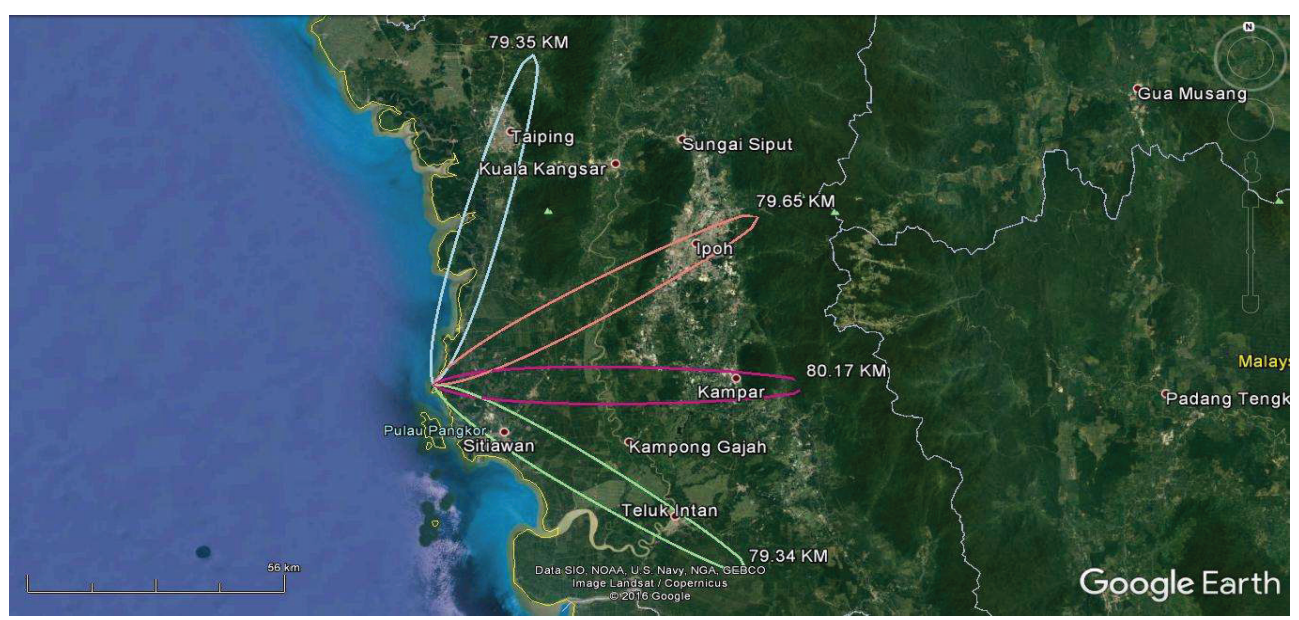

Figure 3: I-131 Total Effective Dose Dispersion in the Region in 4 Wind Direction

Table 2: HotSpot Dose Conversion Data for I-131

\begin{tabular}{|c|c|c|c|c|c|}
\hline $\begin{array}{l}\text { DISTANCE } \\
\mathrm{km}\end{array}$ & $\begin{array}{l}\text { T E D E } \\
(\mathrm{Sv})\end{array}$ & $\begin{array}{c}\text { RESPIRABLE } \\
\text { TIME-INTEGRATED } \\
\text { AIR CONCENTRATION } \\
(\mathrm{Bq}-\mathrm{sec}) / \mathrm{m} 3\end{array}$ & $\begin{array}{c}\text { GROUND SURFACE } \\
\text { DEPOSITION } \\
(\mathrm{kBq} / \mathrm{m} 2)\end{array}$ & $\begin{array}{c}\text { GROUND SHINE } \\
\text { DOSE RATE } \\
(\mathrm{S} v / \mathrm{hr})\end{array}$ & $\begin{array}{l}\text { ARRIVAL } \\
\text { TIME } \\
\text { (hour:min) }\end{array}$ \\
\hline 0.030 & $2.5 \mathrm{E}-03$ & $8.2 E+08$ & $3.5 E+02$ & $4.8 \mathrm{E}-07$ & $<00: 01$ \\
\hline 0.100 & $6.0 \mathrm{E}+01$ & $2.0 \mathrm{E}+13$ & 4. $0 \mathrm{E}+07$ & $5.4 \mathrm{E}-02$ & $<00: 01$ \\
\hline 0.200 & 4. $2 E+01$ & 1. $4 \mathrm{E}+13$ & $2.8 \mathrm{E}+07$ & $3.8 \mathrm{E}-02$ & $00: 01$ \\
\hline 0.300 & 2. $3 E+01$ & 7. $7 E+12$ & 1. $5 \mathrm{E}+07$ & $2.1 \mathrm{E}-02$ & $00: 02$ \\
\hline 0.400 & 1. $4 \mathrm{E}+01$ & $4.6 \mathrm{E}+12$ & $9.2 E+06$ & 1. $3 \mathrm{E}-02$ & $00: 02$ \\
\hline 0.500 & $9.1 \mathrm{E}+00$ & $3.1 \mathrm{E}+12$ & $6.1 \mathrm{E}+06$ & $8.3 E-03$ & $00: 03$ \\
\hline 0.600 & $6.5 \mathrm{E}+00$ & 2. $2 \mathrm{E}+12$ & 4. $3 E+06$ & $5.9 E-03$ & $00: 04$ \\
\hline 0.700 & $4.8 \mathrm{E}+00$ & $1.6 \mathrm{E}+12$ & 3. $2 \mathrm{E}+06$ & $4.4 \mathrm{E}-03$ & $00: 04$ \\
\hline 0.800 & 3. $7 \mathrm{E}+00$ & 1. $3 E+12$ & $2.5 E+06$ & $3.4 \mathrm{E}-03$ & $00: 05$ \\
\hline 0.900 & $3.0 \mathrm{E}+00$ & 1. $0 \mathrm{E}+12$ & $2.0 E+06$ & 2. $7 \mathrm{E}-03$ & $00: 06$ \\
\hline 1.000 & $2.4 \mathrm{E}+00$ & $8.1 E+11$ & $1.6 \mathrm{E}+06$ & $2.2 \mathrm{E}-03$ & $00: 06$ \\
\hline 2.000 & $6.4 \mathrm{E}-01$ & 2. $1 \mathrm{E}+11$ & 4. $3 E+05$ & $5.8 \mathrm{E}-04$ & $00: 13$ \\
\hline 4.000 & 1. $7 \mathrm{E}-01$ & $5.8 \mathrm{E}+10$ & 1. $2 \mathrm{E}+05$ & $1.6 \mathrm{E}-04$ & $00: 27$ \\
\hline 6.000 & $8.1 \mathrm{E}-02$ & 2. $7 E+10$ & $5.5 E+04$ & $7.4 \mathrm{E}-05$ & $00: 40$ \\
\hline 8.000 & $4.8 \mathrm{E}-02$ & $1.6 \mathrm{E}+10$ & $3.3 E+04$ & $4.4 \mathrm{E}-05$ & $00: 54$ \\
\hline 10.000 & 3. $3 \mathrm{E}-02$ & 1. $1 \mathrm{E}+10$ & 2. $2 \mathrm{E}+04$ & $3.0 \mathrm{E}-05$ & $01: 08$ \\
\hline 20.000 & $9.9 \mathrm{E}-03$ & $3.3 E+09$ & $6.7 E+03$ & $9.0 \mathrm{E}-06$ & $02: 16$ \\
\hline 40.000 & $3.2 \mathrm{E}-03$ & 1. $1 \mathrm{E}+09$ & $2.1 \mathrm{E}+03$ & $2.9 E-06$ & $04: 32$ \\
\hline 60.000 & $1.6 \mathrm{E}-03$ & $5.5 E+08$ & 1. $1 \mathrm{E}+03$ & $1.5 \mathrm{E}-06$ & $06: 48$ \\
\hline 80.000 & 1. $0 \mathrm{E}-03$ & $3.5 \mathrm{E}+08$ & 7. $0 \mathrm{E}+02$ & $9.4 \mathrm{E}-07$ & $09: 05$ \\
\hline
\end{tabular}

Table 3: HotSpot Dose Conversion Data for Cs-137

\begin{tabular}{|c|c|c|c|c|c|}
\hline $\begin{array}{l}\text { DISTANCE } \\
\qquad \mathrm{km}\end{array}$ & $\begin{array}{l}\text { T E D E } \\
(S v)\end{array}$ & $\begin{array}{c}\text { RESPIRABLE } \\
\text { TIME-INTEGRATED } \\
\text { AIR CONCENTRATION } \\
(\mathrm{Bq}-\mathrm{sec}) / \mathrm{m} 3\end{array}$ & $\begin{array}{l}\text { GROUND SURFACE } \\
\text { DEPOSITION } \\
(\mathrm{kBq} / \mathrm{m} 2)\end{array}$ & $\begin{array}{l}\text { GROUND SHINE } \\
\text { DOSE RATE } \\
(\mathrm{S} v / \mathrm{hr})\end{array}$ & $\begin{array}{l}\text { ARRIVAL } \\
\text { TIME } \\
\text { (hour:min) }\end{array}$ \\
\hline 0.030 & $2.9 \mathrm{E}-04$ & $1.0 \mathrm{E}+08$ & $4.3 E+01$ & $8.6 \mathrm{E}-08$ & $\angle 00: 01$ \\
\hline 0.100 & 7. $2 \mathrm{E}+00$ & $2.5 E+12$ & $4.9 E+06$ & $9.8 \mathrm{E}-03$ & $<00: 01$ \\
\hline 0.200 & $5.0 \mathrm{E}+00$ & 1. $7 E+12$ & $3.5 E+06$ & $6.9 \mathrm{E}-03$ & $00: 01$ \\
\hline 0.300 & 2. $7 \mathrm{E}+00$ & $9.4 \mathrm{E}+11$ & 1. $9 \mathrm{E}+06$ & $3.8 \mathrm{E}-03$ & $00: 02$ \\
\hline 0.400 & $1.6 \mathrm{E}+00$ & 5. $7 \mathrm{E}+11$ & 1. $1 \mathrm{E}+06$ & 2. $3 \mathrm{E}-03$ & $00: 02$ \\
\hline 0.500 & 1. $1 \mathrm{E}+00$ & $3.8 \mathrm{E}+11$ & $7.5 E+05$ & $1.5 \mathrm{E}-03$ & $00: 03$ \\
\hline 0.600 & 7. $7 \mathrm{E}-01$ & 2. $7 \mathrm{E}+11$ & $5.3 E+05$ & $1.1 \mathrm{E}-03$ & $00: 04$ \\
\hline 0.700 & $5.8 \mathrm{E}-01$ & $2.0 \mathrm{E}+11$ & 4. $0 \mathrm{E}+05$ & $7.9 \mathrm{E}-04$ & $00: 04$ \\
\hline 0.800 & 4. $5 \mathrm{E}-01$ & 1. $5 E+11$ & $3.1 \mathrm{E}+05$ & $6.1 \mathrm{E}-04$ & $00: 05$ \\
\hline 0.900 & $3.6 \mathrm{E}-01$ & 1. $2 \mathrm{E}+11$ & 2. $4 \mathrm{E}+05$ & $4.9 \mathrm{E}-04$ & $00: 06$ \\
\hline 1.000 & 2. $9 \mathrm{E}-01$ & 1. $0 \mathrm{E}+11$ & $2.0 \mathrm{E}+05$ & $4.0 E-04$ & $00: 06$ \\
\hline 2.000 & $7.6 \mathrm{E}-02$ & $2.6 \mathrm{E}+10$ & $5.3 E+84$ & 1. $0 \mathrm{E}-04$ & $00: 13$ \\
\hline 4.000 & $2.1 \mathrm{E}-02$ & $7.1 E+09$ & 1. $4 \mathrm{E}+04$ & 2. $8 \mathrm{E}-05$ & $00: 27$ \\
\hline 6.000 & 9.7E-03 & $3.4 \mathrm{E}+09$ & 6. $7 \mathrm{E}+03$ & 1. $3 \mathrm{E}-05$ & $00: 40$ \\
\hline 8.000 & $5.8 \mathrm{E}-03$ & $2.0 \mathrm{E}+09$ & $4.0 E+03$ & $8.0 \mathrm{E}-06$ & $00: 54$ \\
\hline 10.000 & $3.9 \mathrm{E}-03$ & 1. $3 E+09$ & 2. $7 \mathrm{E}+03$ & $5.4 \mathrm{E}-06$ & $01: 08$ \\
\hline 20.000 & 1. $2 \mathrm{E}-03$ & $4.1 E+08$ & $8.2 E+02$ & 1. $6 \mathrm{E}-06$ & $02: 16$ \\
\hline 40.000 & $3.8 \mathrm{E}-04$ & 1. $3 E+08$ & $2.6 \mathrm{E}+02$ & $5.3 \mathrm{E}-07$ & $04: 32$ \\
\hline 60.000 & 2. $0 \mathrm{E}-04$ & $6.9 \mathrm{E}+07$ & 1. $4 \mathrm{E}+02$ & $2.8 \mathrm{E}-07$ & $06: 48$ \\
\hline 80.000 & 1. $3 \mathrm{E}-04$ & $4.4 E+07$ & $8.8 \mathrm{E}+01$ & $1.8 \mathrm{E}-07$ & $09: 05$ \\
\hline
\end{tabular}


From the simulation, total effective dose equivalent (TEDE) and dose rate for Cs-137 and I-131 is calculated for 60 minutes from the onset of the postulated accident. The highest expected TEDE is when the radionuclides blasted out from the NPP core with the value of $60 \mathrm{~Sv}$; with dose rate $0.54 \mathrm{mSv} \mathrm{hr}^{-1}$ and $9.8 \mathrm{mSv} \mathrm{hr}^{-1}$ for Cs-137 and I-131 respectively. As the dose decreases with time, the detected TEDE after 1 hour is $33 \mathrm{mSv}$ and $3.9 \mathrm{mSv}$ for Cs-137 and I-131 at $10 \mathrm{~km}$ from the point source with the respective dose rate of $5.4 \times 10^{-6}$ $\mathrm{Sv} \mathrm{hr}{ }^{-1}$ for Cs-137 and $3.0 \times 10^{-5} \mathrm{~Sv} \mathrm{hr}^{-1}$ for I-131. After 4 hours, the TEDE detected is 0.38 $\mathrm{mSv}$ for Cs-137 and $3.2 \mathrm{mSv}$ for I-131, at $40 \mathrm{~km}$ distance from the site with dose rate of 5.3 x $10^{-4} \mathrm{mSv} \mathrm{hr}^{-1}$ and $2.9 \times 10^{-3} \mathrm{mSv} \mathrm{hr}^{-1}$ respectively.

\section{Discussion}

This study shows the radioactive dispersion analysis of Cs-137 and I-131 in CS1, should the similar accident equivalent to Fukushima happen in the candidate site. The result shows that both radionuclides can reach the nearest town, Lumut and Sitiawan, which located 18 $\mathrm{km}$ from the CS1 in less than 3 hours from the accident time. Both radionuclides can also reach major towns such as Taiping, Ipoh, Kampar and Teluk Intan that located around 60 $\mathrm{km}$ from CS1 in less than 8 hours from the accident time. From the observation, although Lumut and Sitiawan are close to the site, both towns are protected by hilly terrains more than 100 meters high, which become a natural barrier from direct radioactive dispersion. Hence, both towns are considered protected from accidental or normal radioactive dispersion of NPP in CS1.

To estimate radiological risks from the postulated accident for Taiping, Ipoh, Kampar and Teluk Intan, total effective dose received from Cs-137 and I-131 during accident is calculated. For Cs-137, estimated total dose received at the major towns which is around 65 $\mathrm{km}$ from CS1 is $0.2 \mathrm{mSv}$ (dose rate received less than 7 hours after incident time) during the incident. Since the TEDE and dose rate will decrease with time and distance, the most likely effective dose rate is less than $1 \mathrm{mSv} \mathrm{yr}^{-1}$. For I-131, the estimated total dose rate received at Taiping, Ipoh, Kampar and Teluk Intan is $1.6 \mathrm{mSv}$ during the accident. However, since I-131 half life is only 8 days, the dose rate is expected to decrease drastically throughout the year and may results annual dose rate less than $1 \mathrm{mSv} \mathrm{yr}^{-1}$.

Since the estimated annual effective dose is lower the global limit, the NPP candidate site in this study can be considered safe for NPP construction. However more detailed analysis should be conducted in risk assessment before the decision to select CS1 as NPP site can be made.

\section{CONCLUSION}

The dispersion analysis for NPP candidate site CS1 is conducted using HotSpot software based on Fukushima Accident in 2011 and it shows that the radionuclide dispersion can reach as far as $80 \mathrm{~km}$ from the site, where the Perak capital, Ipoh is located. However, estimated annual effective dose is not more than $1 \mathrm{mSv}$ limit, which is considered acceptable in the point of view of radiological health risk for human and the environment. However, more studies should be conducted to ensure all radiological risks and hazards are identified before the decision to select CS1 as NPP site can be made. 
One of the author (SDS) would like to thank the Ministry of Higher Education (MOHE) Malaysia and Universiti Teknologi Malaysia for providing a GUP grant Q.J130000.2526.12H21 for this research.

\section{REFERENCES}

[1] WNA, (2015). Nuclear Share Figures, 2004-2014. World Nuclear Association. Web article from: http://www.world-nuclear.org/info/Facts-and-Figures/Nucleargeneration-by-country/ [Extracted at $19^{\text {th }}$ January 2016].

[2] Jewell, J., (2011). Ready for nuclear energy?: An assessment of capacities and motivations for launching new national nuclear power programs. Energy Policy. $39,1041-155$.

[3] WNA, (2016). Emerging Nuclear Energy Countries. World Nuclear Association. Web article from: http://www.world-nuclear.org/info/CountryProfiles/Others/Emerging-Nuclear-Energy-Countries/ $\quad\left[\right.$ Extracted at $19^{\text {th }}$ January 2016].

[4] Basri, N.A., Ramli, A.T., Aliyu, A.B.S., (2015). Malaysia energy strategy towards Sustainability: a panoramic overview of the benefits and challenges. Renewable and Sustainable Energy Reviews. 42, 1094-1105.

[5] Aliyu, A.B.S., Ramli, A.T., Salleh, M.A., (2015). Assessment of potential human health and environmental impacts of a nuclear power plant (NPP) based on atmospheric modeling. Atmosfera. 28(1), 13-26.

[6] IAEA, (2003). Site Evaluation For Nuclear Installations. International Atomic Energy Agency. Vienna, Austria.

[7] AELB, (2011). Guideline For Site Evaluation For Nuclear Power Plant. Atomic Energy Licensing Board.

[8] Pasquill, F. (1961). The estimation of the dispersion of windborne material. The Meteorological Magazine, vol 90, No. 1063, pp 33-49.

[9] Homann, S.G. and Aluzzi, F., (2014). HotSpot Health Physics Codes User's Guide Version 3.0. National Atmospheric Release Advisory Center, Lawrence Livermore National Laboratory, California, 198 pp.

[10] Department of Statistics, (2010). Basic Population Characteristics by Administrative Districts. Census Report 2010. Malaysia Department of Statistics. Kuala Lumpur, Malaysia.

[11] Hirose, K. (2012). 2011 Fukushima Dai-ichi nuclear power plant accident: summary of regional radioactive deposition monitoring results. Journal of Environmental Radioactivity, 111, 13-17.

[12] Korsakissok, I., Mathieu, A., \& Didier, D. (2013). Atmospheric dispersion and ground deposition induced by the Fukushima Nuclear Power Plant accident: A localscale simulation and sensitivity study. Atmospheric Environment, 70, 267-279.

[13] Katata, G., Ota, M., Terada, H., Chino, M., \& Nagai, H. (2012). Atmospheric discharge and dispersion of radionuclides during the Fukushima Dai-ichi Nuclear Power Plant accident. Part I: Source term estimation and local-scale atmospheric dispersion in early phase of the accident. Journal of Environmental Radioactivity, 109, 103-113. 